\title{
Pemodelan Persamaan Hubungan Kualitas Perairan Menggunakan Citra Landsat 8 untuk Pendugaan Habitat Padang Lamun (Studi Kasus: Pantai Sanur, Bali)
}

\author{
Muhammad Wahyu Tri Pamungkas ${ }^{1}$, Lalu Muhamad Jaelani ${ }^{1}$ \\ ${ }^{1}$ Jurusan Teknik Geomatika, Fakultas Teknik Sipil dan Perencanaan Institut Teknologi Sepuluh Nopember (ITS) \\ Kampus ITS, Sukolilo, Surabaya 60111 Indonesia \\ e-mail:1mjaelani@geodesy.its.ac.id
}

\begin{abstract}
Abstrak - Padang lamun adalah salah satu jenis vegetasi yang berperan penting di ekosistem laut, karena merupakan sumber pakan dan tempat tinggal bagi ikan dan biota laut lain, serta sebagai pencegah abrasi pantai. Namun, ekosistem ini kurang mendapat perhatian dan terus mengalami kerusakan, salah satunya yaitu ekosistem lamun di pantai Sanur yang merupakan daerah wisata, dimana kerusakannya mencapai sekitar $15 \%$. Sehingga perlu dilakukan pengamatan perubahan habitat lamun secara temporal untuk memantau kerusakan yang terjadi. Pengamatan perubahan habitat lamun dilakukan menggunakan persamaan hubungan antara kualitas perairan, yang meliputi suhu, salinitas, kecerahan, dan kedalaman perairan terhadap habitat padang lamun yang didasarkan pada rentang nilai kualitas perairan yang sesuai bagi habitat lamun menurut Peraturan Menteri Negara Lingkungan Hidup No. 51 Tahun 2004. Data kualitas perairan diperoleh dari pengolahan citra satelit Landsat 8 tahun 2014 dan 2015 menggunakan algoritma pengolah citra yang telah ada. Berdasarkan data lapangan, diperoleh koefisien pengaruh suhu terhadap keberadaan lamun sebesar $\mathbf{- 0 , 0 4 5 7 4}$, koefisien salinitas sebesar 0,40224 , koefisien

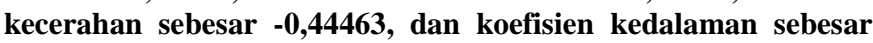
0,61788. Dengan memasukkan data kualitas perairan ke dalam persamaan hubungan tersebut, diperoleh perubahan habitat padang lamun. Pada tahun 2014 diperoleh luas 393,62 Ha yang sesuai bagi habitat padang lamun, kemudian berkurang 39,11 Ha menjadi 354,51 Ha pada tahun 2015.
\end{abstract}

Kata kunci - Habitat Lamun, Landsat 8, Pantai Sanur, Perubahan Kualitas Perairan

\section{PENDAHULUAN}

$\mathrm{W}$ ILAYAH pesisir adalah daerah peralihan antara ekosistem darat dan laut yang dipengaruhi oleh perubahan di darat dan laut, dimana wilayah ini mencakup sumber daya hayati, sumber daya nonhayati, sumber daya buatan, dan jasa-jasa lingkungan, salah satunya yaitu ekosistem padang lamun [1]. Padang lamun di Indonesia memiliki luas sekitar $30.000 \mathrm{~km}^{2}$ dan berperan penting di ekosistem laut dangkal, karena merupakan habitat bagi ikan dan biota perairan lainnya [2]. Lamun merupakan sumber pakan bagi invertebrata (feeding ground), tempat tinggal, dan tempat asuhan biota perairan agar tidak tersapu arus laut (nursery ground), serta tempat memijah (spawning ground) yang melindunginya dari serangan predator. Lamun juga menyokong rantai makanan dan penting dalam proses siklus nutrien, serta sebagai pelindung pantai dari ancaman erosi ataupun abrasi [3].

Tidak seperti ekosistem terumbu karang, rumput laut, dan mangrove, ekosistem lamun sampai saat ini masih kurang mendapat perhatian [4]. Hal ini dikarenakan kurangnya pengetahuan masyarakat tentang fungsi ekosistem lamun dan dikarenakan masyarakat belum dapat mengambil manfaat langsung dari lamun. Akibatnya, upaya masyarakat dalam menjaga kelestarian ekosistem ini sangat minim, bahkan terkadang dianggap sebagai tanaman pengganggu, sehingga akhirnya diabaikan atau dimusnahkan [4].

Pentingnya peran padang lamun di ekosistem laut dangkal tidak menjamin ekosistem ini tetap terjaga, diperkirakan kerusakan padang lamun di Indonesia telah mencapai 3040\%. Sekitar $60 \%$ padang lamun di perairan pesisir Pulau Jawa telah mengalami gangguan berupa kerusakan dan pengurangan luas yang diduga akibat pengaruh aktivitas manusia [5].

Selain aktivitas manusia, kerusakan padang lamun juga diakibatkan oleh perubahan kualitas perairan tempat habitat hidupnya. Faktor lingkungan yang berpengaruh langsung bagi kelangsungan hidup lamun diantaranya yaitu salinitas, suhu, dan kecerahan perairan [6]. Sehingga bila kualitas perairan lingkungan hidupnya mengalami perubahan, akan mengakibatkan perubahan atau bahkan kerusakan terhadap tumbuhan lamun itu sendiri.

Salah satu lokasi yang mengalami kerusakan padang lamun yaitu di pantai Sanur, Bali. Kerusakan dan hilangnya padang lamun di Pantai Sanur mencapai sekitar 15\%. Padang lamun di kawasan pantai Sanur termasuk dalam kawasan pariwisata dan sebagian arealnya dijadikan lokasi penambatan kapal atau perahu. Dimana kerusakan lamun terjadi karena pada saat 
surut, dimana dasar kapal atau perahu langsung menutupi lamun dan mematikan lamun yang cukup luas karena posisi kapal berpindah-pindah setiap air surut [7].

Untuk mengetahui perubahan pada padang lamun, perlu dilakukan pengamatan secara temporal, terutama terkait masalah perubahan komposisi jenis, kerapatan, persen penutupan, luas tutupan lamun, dan kualitas perairan agar dapat diketahui luas perubahan serta dapat dilakukan perencanaan rahabilitasi. Laporan perubahan luas lamun secara temporal tidak mudah untuk diperoleh, dibutuhkan banyak data dengan penggunaan biaya yang tidak sedikit, sehingga diperlukan suatu metode yang lebih efisien. Salah satu metode yang dapat digunakan adalah dengan menggunakan teknologi penginderaan jauh [3].

Penginderaan jauh (remote sensing) adalah seni atau ilmu untuk mendapatkan informasi tentang obyek, area, atau fenomena melalui analisis terhadap data yang diperoleh dengan menggunakan alat tanpa kontak langsung dengan obyek, daerah, ataupun fenomena yang dikaji. Alat yang dimaksud pada penginderaan jauh ini adalah alat pengindera atau sensor [3].

\section{URAIAN PENELITIAN}

\section{A. Lokasi Penelitian}

Pantai Sanur terletak diantara koordinat $08^{\circ} 38^{\prime} 00^{\prime \prime}$ LS $08^{\circ} 42^{\prime} 30^{\prime \prime}$ LS dan $115^{\circ} 14^{\prime} 30^{\prime \prime}$ BT - 115'16’30” BT. Luas wilayah kawasan pariwisata pantai Sanur adalah 1.548,27 Ha. Kawasan pariwisata Sanur memiliki garis pantai dengan panjang $\pm 7 \mathrm{~km}$, merupakan pantai di sebelah timur Bali yang membentang dari utara ke selatan [2]. Kawasan ini meliputi beberapa pantai, yaitu pantai Mertasari, Semawang, Indah, Sindhu, Inna Grand Bali, Sanur, dan Matahari Terbit.

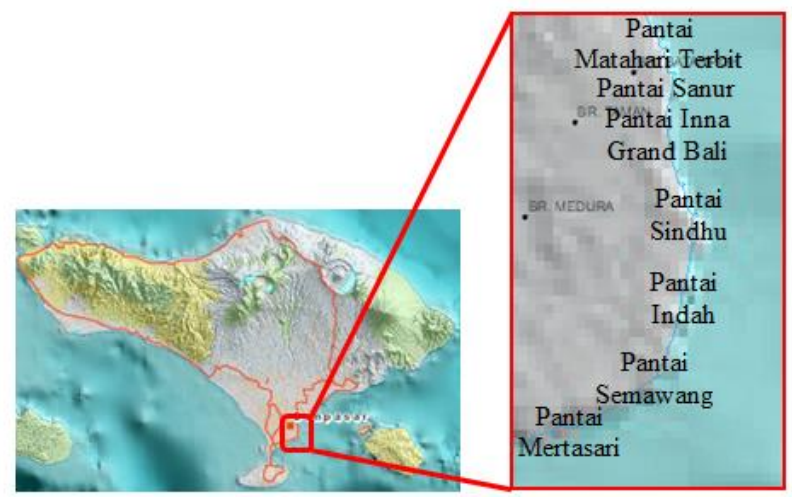

Gambar 1. Lokasi Penelitian

\section{B. Data dan Peralatan}

Terdapat 3 jenis data yang digunakan pada penelitian ini, yaitu data lapangan berupa koordinat persebaran padang lamun serta parameter kualitas perairan, yang meliputi suhu permukaan laut, salinitas, dan kecerahan perairan. Kemudian data kedalaman laut dari peta hipsografi digital BIG skala 1:50.000, serta data citra satelit Landsat 8 tahun 2014 dan 2015 di wilayah pantai Sanur, Bali.

Sementara peralatan yang digunakan dalam penelitian tugas akhir ini yaitu GPS, secchi disk, infrared thermometer, dan refracto salinometer yang digunakan untuk pengambilan data lapangan. Kemudian untuk pengolahan data, digunakan perangkat lunak Visat 5.0, ArcGIS 10.2.2 Trial, dan Matlab R2015a Trial.

\section{Tahap Pengolahan Data}

Langkah pertama yang dilakukan pada penelitian ini adalah mengolah data citra untuk mendapatkan nilai kualitas perairan. Dimana terlebih dahulu dilakukan kalibrasi radiometrik untuk merubah nilai DN (Digital Number) menjadi nilai radian ToA (Top of Atmospheric). Kemudian dilakukan koreksi atmosfer pada data radian ToA sehingga didapat nilai data reflektan $B o A$. Proses koreksi atmosfer ini dilakukan dengan menggunakan metode 6S [8].

Setelah dilakukan koreksi radiometrik, kemudian dilakukan pengolahan kualitas perairan menggunakan algoritma yang telah ada. Untuk suhu, digunakan algoritma hasil pengolahan [9], yaitu:

$$
\text { Suhu }=-0,0197 \times(X)^{2}+(0,2881 \times X)+29,004
$$

dimana X merupakan nilai radian kanal 11 (LWIR-2) pada citra Landsat 8.

Untuk pengolahan salinitas [10], digunakan algoritma hasil pengolahan, yaitu:

$$
\text { Salinitas }=10^{\left(-0,141 \times c_{\mathrm{P}}\right)+1,45}
$$

dimana nilai $\mathrm{c}_{\mathrm{p}}$ (surface water beam attenuation coefficient) diperoleh melalui persamaan berikut:

$$
\begin{gathered}
\mathrm{c}_{\mathrm{P}}=\left(0,70 \times \mathrm{MNDCI}^{3}\right)+\left(0,96 \times \mathrm{MNDCI}^{2}\right)+ \\
(1,14 \times \mathrm{MNDCI})-0,25
\end{gathered}
$$

dimana MNDCI (Maximum Normalized Difference Carbon Index) dapat diperoleh dengan persamaan berikut:

$$
\text { MNDCI }=\frac{\mathrm{L}_{B o A \text { kanal hijau }-} \mathrm{L}_{B o A \text { kanal biru }}}{\mathrm{L}_{B o A \text { kanal hijau }+} \mathrm{L}_{B o A \text { kanal biru }}}
$$

Sementara untuk pengolahan kecerahan, digunakan algoritma hasil pengolahan [11], yaitu:

$$
\text { Kecerahan }=100000000 \times \mathrm{e}^{-24,93 \mathrm{X}}
$$

dimana $\mathrm{X}$ diperoleh dengan persamaan berikut:

$$
\mathrm{X}=\frac{\log R \mathrm{rs}_{(\lambda) \text { kanal biru }}}{\log R \mathrm{rs}_{(\lambda) \text { kanal merah }}}
$$

Sementara data lapangan digunakan untuk pembuatan persamaan hubungan antara kualitas perairan yang meliputi suhu, salinitas, kecerahan, dan kedalaman terhadap keberadaan padang lamun. Dimana hasil survei lapangan dan data kedalaman dibuat ke dalam rentang nilai yang sama, yaitu 0 dan 1. Pembagian tersebut mengacu pada kondisi perairan yang sesuai bagi habitat padang lamun. Bila kondisinya sesuai bagi habitat padang lamun, maka data 
bernilai 1 , namun bila kondisinya tidak sesuai, maka data bernilai 0 .

Tabel 1.

Parameter Kualitas Perairan

\begin{tabular}{lcc}
\hline \hline \multicolumn{1}{c}{ Parameter } & 1 & 0 \\
\hline Suhu & $28-30{ }^{\circ} \mathrm{C}$ & $<28^{\circ} \mathrm{C}$ atau $>30^{\circ} \mathrm{C}$ \\
Salinitas & $33-34$ psu & $<33$ psu atau $>34$ psu \\
Kecerahan & $>3$ meter & $<3$ meter \\
Kedalaman & $<4$ meter & $>4$ meter \\
\hline \hline
\end{tabular}

Setelah nilai data kualitas perairan berada pada rentang yang sama, kemudian dicari pengaruh hubungan kualitas perairan terhadap keberadaan padang lamun berdasarkan persamaan:

$$
\mathrm{Y}=\mathrm{aw}+\mathrm{bx}+\mathrm{cy}+\mathrm{dz}
$$

Y adalah habitat padang lamun, a, b, c, dan d adalah koefisien pengaruh kualitas perairan terhadap habitat padang lamun, w, $\mathrm{x}, \mathrm{y}$, dan $\mathrm{z}$ adalah nilai kualitas perairan (0 atau 1) dari data lapangan. Nilai a, b, c, dan d diperoleh melalui penghitungan matriks berdasarkan persamaan berikut:

$$
X=A^{T} A \times A^{T} L
$$

$\mathrm{X}$ adalah matriks koefisien ( $\mathrm{a}, \mathrm{b}, \mathrm{c}, \mathrm{d}), \mathrm{A}$ adalah matriks kualitas perairan (suhu, salinitas, kecerahan, kedalaman), dan $\mathrm{L}$ adalah matriks keberadaan padang lamun.

\section{HASIL DAN ANALISIS}

\section{A. Suhu Permukaan Laut}

Dari hasil pengolahan suhu permukaan laut, didapat hasil sebagai berikut:

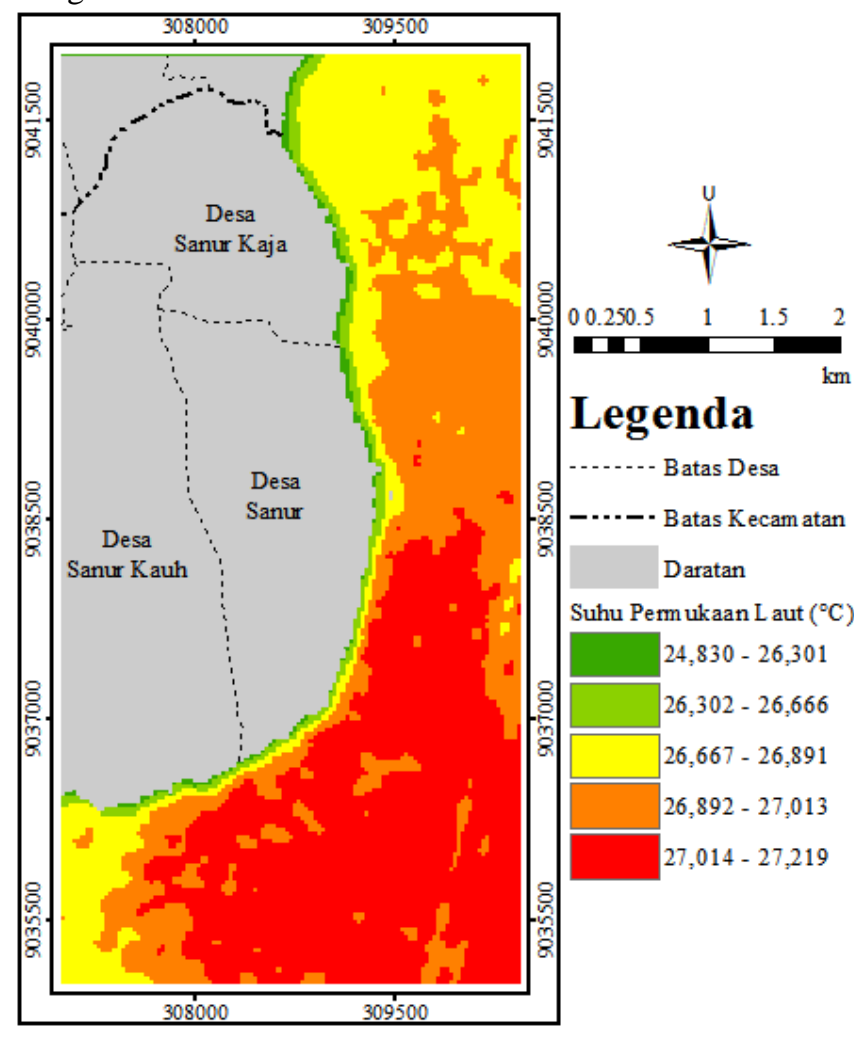

Gambar 2. Sebaran Suhu Permukaan Laut Tahun 2014

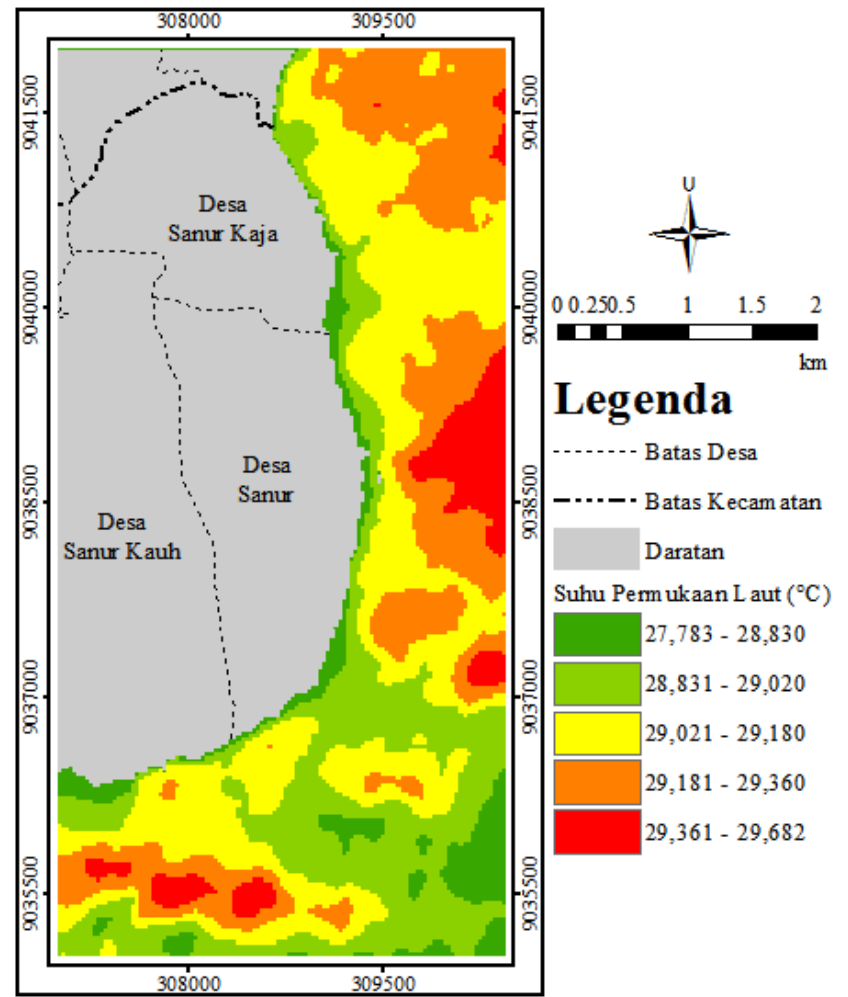

Gambar 3. Sebaran Suhu Permukaan Laut Tahun 2015

Pada tahun 2014, suhu permukaan laut di wilayah perairan pantai Sanur berkisar antara $24,83-27,22{ }^{\circ} \mathrm{C}$, rentang suhu tersebut kurang sesuai bagi habitat lamun menurut Peraturan Menteri Lingkungan Hidup, yaitu berkisar antara $28-30{ }^{\circ} \mathrm{C}$. Sementara pada tahun 2015, kisaran suhu meningkat menjadi 27,78-29,68 ${ }^{\circ} \mathrm{C}$, sehingga hampir seluruh wilayah perairan pantai Sanur memiliki rentang suhu yang sesuai bagi habitat padang lamun.

\section{B. Salinitas Perairan}

Dari hasil pengolahan salinitas, pada semua data baik tahun 2014 maupun 2015, wilayah dengan salinitas perairan yang sesuai bagi habitat padang lamun yaitu berada di daerah lepas pantainya. Sementara pada daerah pesisir pantai, memiliki nilai salinitas yang lebih rendah. Terjadi perubahan nilai rentang salinitas pada setiap data, dimana pada tahun 2014, nilai salinitas berkisar antara 28,41-35,46 psu. Sementara pada tahun 2015, kisaran salinitas berkurang menjadi 29,2534,04 psu. Meskipun nilai rentang salinitas berubah, namun sebagian besar wilayah masih memiliki nilai salinitas yang sesuai. Rentang salinitas yang sesuai bagi habitat padang lamun tersebut yaitu menurut Peraturan Menteri Lingkungan Hidup berkisar antara 33-34 psu. 


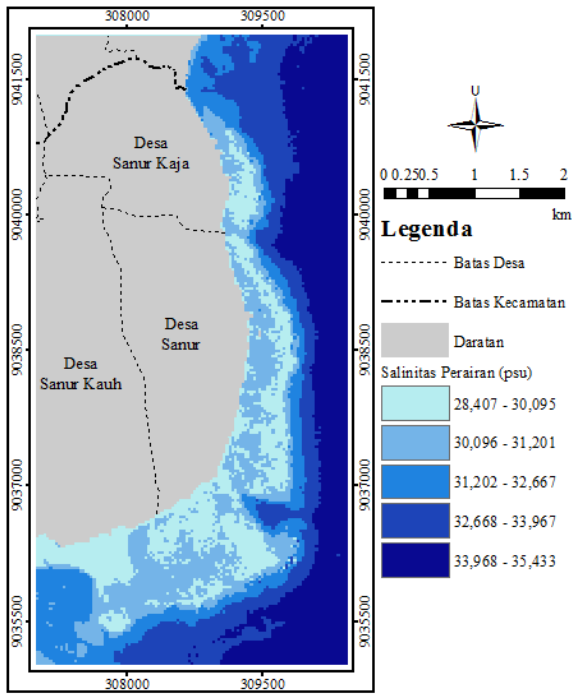

Gambar 4. Sebaran Salinitas Perairan Tahun 2014

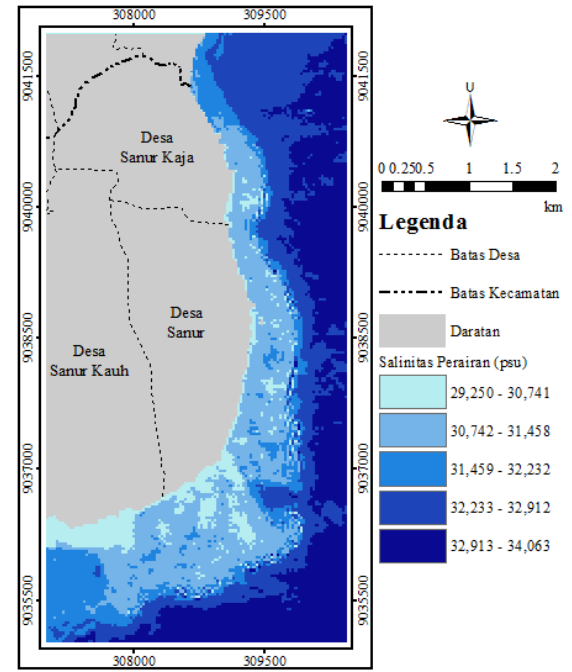

Gambar 5. Sebaran Salinitas Perairan Tahun 2015

\section{Kecerahan Perairan}

Dari hasil pengolahan kecerahan, didapat hasil sebagai berikut:

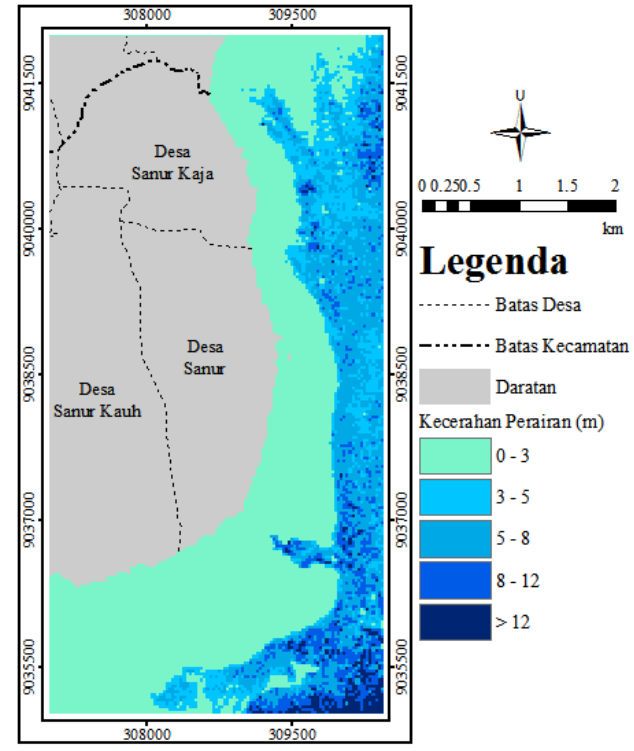

Gambar 6. Kecerahan Perairan Tahun 2014
Pada tahun 2014, kecerahan perairan berkisar antara 037,16 meter. Dimana kecerahan yang sesuai bagi habitat padang lamun menurut pada Peraturan Menteri Lingkungan Hidup, yaitu lebih dari 3 meter berada di seluruh wilayah perairan lepas pantai.

Sementara pada tahun 2015, kecerahan perairan berkisar antara 0-15,34 meter. Dimana hampir seluruh wilayah perairan tidak sesuai bagi habitat padang lamun. Perairan yang sesuai hanya berada di perairan lepas pantai Mertasari.

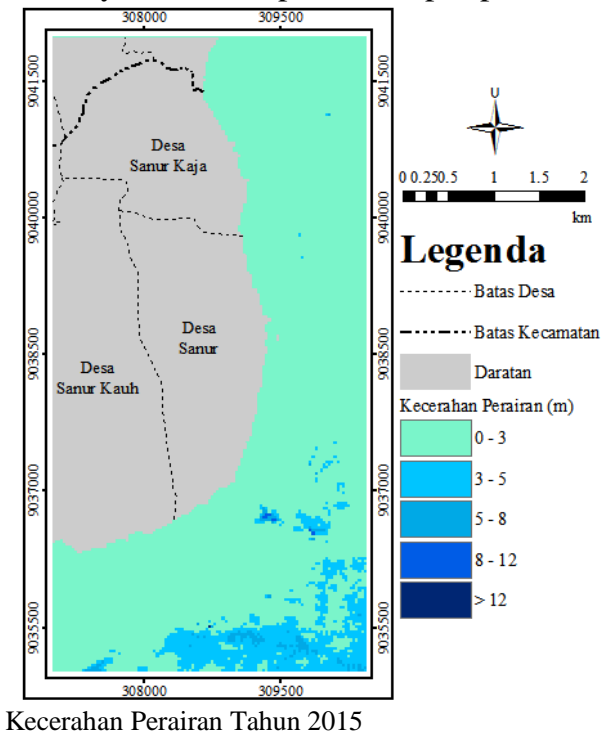

Gambar 7. Kecerahan Perairan Tahun 2015

\section{Persamaan Hubungan Kualitas Perairan Terhadap Habitat Padang Lamun}

Dari hasil penghitungan, didapat persamaan untuk menentukan daerah yang sesuai bagi habitat padang lamun sebagai berikut:

$$
\begin{array}{r}
\text { Habitat lamun }=-0,04574 \times \mathrm{W}+0,40224 \times \mathrm{X} \\
-0,44463 \times \mathrm{Y}+0,61788 \times \mathrm{Z}
\end{array}
$$

dimana $\mathrm{W}$ adalah suhu, $\mathrm{X}$ adalah salinitas, $\mathrm{Y}$ adalah kecerahan, dan $\mathrm{Z}$ adalah kedalaman.

Dari persamaan (9), dapat diketahui bahwa parameter yang paling berpengaruh terhadap keberadaan padang lamun yaitu kedalaman perairan karena memiliki nilai koefisien yang paling besar. Kemudian salinitas dan kecerahan perairan memiliki nilai koefisien yang hampir sama, sehingga kedua parameter tersebut memiliki pengaruh yang hampir sama. Sementara itu, suhu permukaan laut memiliki pengaruh yang paling kecil terhadap keberadaan lamun dibandingkan parameter kualitas perairan yang lain.

Namun, terdapat dua parameter yang bernilai negatif, yaitu suhu dan kecerahan perairan. Hal itu berarti bila nilai suhu dan kecerahan masuk ke dalam rentang menurut Peraturan Menteri Lingkungan Hidup, justru membuat wilayah perairan menjadi tidak sesuai bagi habitat padang lamun.

Nilai koefisien kecerahan bernilai negatif disebabkan karena di wilayah pantai Sanur, padang lamun tumbuh di perairan yang dangkal, dimana nilai kecerahannya rendah. Sementara koefisien suhu bernilai negatif disebabkan karena 
data suhu yang diperoleh pada saat pengambilan data lapangan berada di bawah rentang kesesuaian menurut Peraturan Menteri Lingkungan Hidup.

\section{E. Perubahan Kesesuaian Habitat Padang Lamun}

Citra sebaran suhu, salinitas, dan kecerahan perairan serta data kedalaman yang telah diolah kemudian dimasukkkan ke dalam persamaan hubungan pengaruh kualitas perairan terhadap habitat padang lamun (persamaaan (9)), sehingga diketahui wilayah mana saja yang sesuai bagi habitat lamun. Berikut adalah wilayah yang sesuai bagi habitat lamun:

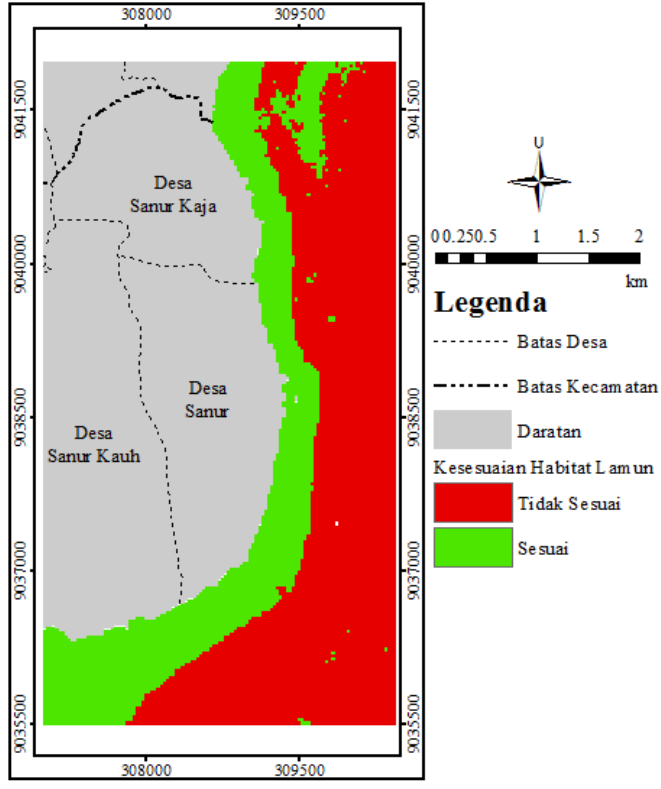

Gambar 8. Habitat Padang Lamun Tahun 2014

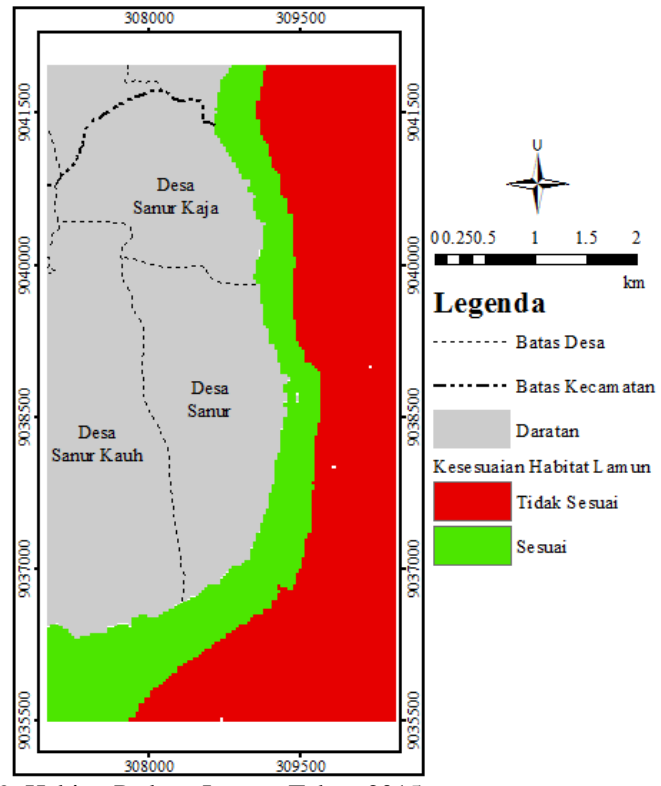

Gambar 9. Habitat Padang Lamun Tahun 2015

Pada tahun 2014, daerah yang sesuai bagi habitat padang lamun yaitu berada di seluruh wilayah pesisir pantai Sanur dan lepas pantai Matahari Terbit. Sementara pada tahun 2015, terdapat perbedaan daerah yang sesuai bagi habitat padang lamun yaitu di wilayah lepas pantai Matahari Terbit.
Perubahan habitat padang lamun ini disebabkan oleh perubahan sebaran salinitas dan kecerahan perairan di wilayah perairan pantai Sanur, sementara peningkatan suhu tidak begitu berpengaruh karena suhu memiliki koefisien yang paling kecil.

Sementara itu, perubahan luas habitat padang lamun dapat dilihat pada tabel berikut:

Tabel 2.

Perubahan Luas Habitat Lamun

\begin{tabular}{cc}
\hline Tahun & Luas (Ha) \\
\hline 2014 & 393,62 \\
2015 & 354,51 \\
\hline \hline
\end{tabular}

Terjadi pengurangan luasan habitat yang sesuai bagi padang lamun. Pada tahun 2014, wilayah yang sesuai bagi habitat padang lamun yaitu seluas 393,62 Ha, kemudian berkurang 39,11 Ha menjadi 354,51 Ha pada tahun 2015.

\section{KESIMPULAN DAN SARAN}

Kesimpulan dari penelitian ini yaitu parameter kualitas perairan yang paling berpengaruh pada habitat padang lamun adalah kedalaman, dengan koefisien sebesar 0,61788. Kemudian salinitas dan kecerahan memiliki pengaruh yang hampir sama, dengan koefisien sebesar 0,40224 dan -0,44463. Sementara suhu permukaan laut memiliki pengaruh yang paling kecil, yaitu sebesar $-0,04574$.

Terjadi penurunan wilayah yang sesuai bagi habitat padang lamun. Dimana terjadi penurunan sebesar 1,23 Ha, dari 355,74 Ha pada tahun 2014 menjadi 354,51 Ha pada tahun 2015.

Sementara saran dari penelitian ini adalah diperlukan data lapangan keberadaan padang lamun pada musim kemarau, sehingga didapat persamaan hubungan pengaruh kualitas perairan terhadap keberadaan padang lamun yang lebih akurat. Serta diperlukan analisis dengan data pada musim yang berbeda untuk mengetahui pengaruh musim bagi habitat padang lamun.

\section{DAFTAR PUSTAKA}

[1] U. 1945, "Undang-undang No.1 Tahun 2014 Tentang Perubahan Atas Undang-undang Nomor 27 Tahun 2007 Tentang Pengelolaan Wilayah Pesisir dan Pulau-pulau Kecil".

[2] R. Oktaviyanti, Suryanti and Frida, "Kelimpahan Echinodermata pada Ekosistem Padang Lamun di Pulau Panggang, Kepulauan Seribu, Jakarta," Diponegoro Journal of Mauares, vol. 3, no. 4, pp. 243-249, 2014.

[3] I. S. Simanjuntak, "Pengolahan Data Sebaran Padang Lamun menggunakan Data Citra Landsat 8 di Kawasan Perairan Pulau Pari, Kepulauan Seribu, DKI Jakarta," Laporan Kerja Praktik: Program Studi Ilmu Kelautan, Universitas Sriwijaya, Palembang, 2015.

[4] R. Hartati, A. Djunaedi and H. Mujiyanto, "Struktur Komunitas Padang Lamun di Perairan Pulau Kumbang, Kepulauan Karimunjawa," Jurnal Ilmu Kelautan, vol. 17, no. 4, pp. 217-225, 2012.

[5] F. Setiawan, S. A. Harahap, Y. Andriani and A. A. Hutahaean, "Deteksi Perubahan Padang Lamun menggunakan Teknologi Penginderaan Jauh dan Kaitannya dengan Kemampuan Menyimpan Karbon di Perairan Teluk Banten," Jurnal Kelautan dan Perikanan, vol. 3, no. 3, pp. 275286, 2012. 
[6] M. N. L. Hidup, "Keputusan Menteri Negara Lingkungan Hidup No. 51 Tahun 2004 Tentang Baku Mutu Air Laut," Indonesia.

[7] Y. I. Graha, "Simpanan Karbon Padang Lamun di Kwasan Pantai Sanur, Kota Denpasar," Thesis PRrogram Pascasarjana: Universitas Udayana, Denpasar, 2015.

[8] Z. Afifi, "Studi Pemetaan Fenomena Pemutihan Terumbu Karang (Coral Bleaching) menggunakan Citra Satelit Worldview-2 (Studi Kasus: Perairan PLTU Paiton, Jawa Timur)," Skripsi: Jurusan Teknik Geomatika, ITS, Surabaya, 2015.

[9] M. A. Syariz, L. M. Jaelani, L. Subehi, A. Pamungkas, E. S. Koenhardono and A. Sulisetyono, "Retrieval of Sea Surface Temperature Over Poteran Island Water of Indonesia with Landsat 8 TIRS Image: A Preliminary Algorithm," The International Archives of The Photogrammetry, Remote Sensing, and Spatial Information Sciences, vol. XI, no. 2, pp. 87-90, 2015.

[10] Y. B. Son, W. D. Gardner, J. Mary, J. Ishizaka, M. J. Richardson, J. H. Ryu, S. H. Kim and S. H. Lee, "Tracing Offshore Low-Salinity Plumes in the Northeastern Gulf of Mexico During the Summer Season by Use of Multispectral Remote-Sensing Data," Journal of Oceanography, vol. 68, no. 5, pp. 743-760, 2012.

[11] M. A. Shodiqin, "Studi Total Suspendid Solid dan Transparansi Perairan menggunakan Citra Satelit Wordview-2 sebagai Faktor Pembatas Pertumbuhan Terumnu Karang (Studi Kasus: Perairan PLTU Paiton, Kabupaten Probolinggi)," Tugas Akhir: Jurusan Teknik Geomatika, ITS, Surabaya, 2015. 